\title{
Price Discrimination in the Airline Market: The Effect of Market Concentration
}

\author{
Joanna Stavins * \\ Federal Reserve Bank of Boston \\ 600 Atlantic Avenue \\ Boston, MA 02106 \\ (617) 973-4217 \\ e-mail: joanna.stavins@bos.frb.org
}

November 25, 1996

* Economist, Federal Reserve Bank of Boston. The views expressed in this paper are those of the author and do not necessarily reflect the official views of the Federal Reserve Bank of Boston or the Federal Reserve System. 


\title{
Price Discrimination in the Airline Market: The Effect of Market Concentration
}

\author{
Joanna Stavins
}

\begin{abstract}
Economic theory suggests that a monopolist can price discriminate more successfully than can a perfectly competitive firm. Most real-life markets, however, fall somewhere in between the two extremes. What happens as the market becomes more competitive: Does price discrimination increase or decrease? This paper examines how price discrimination changes with market concentration in the airline market. The paper uses data on prices and ticket restrictions across various routes within the United States, controlling for distances and airport gate restrictions. Price discrimination is found to increase as the markets become more competitive.
\end{abstract}




\section{Price Discrimination in the Airline Market: \\ The Effect of Market Concentration \\ Joanna Stavins}

In a perfectly competitive market, firms have no market power to discriminate by price. At the other extreme, a monopolist can, provided he has information about consumers' taste differences and the transaction costs of setting multiple prices do not prevent such pricing strategies. Most real-life markets, however, fall somewhere in between the two extremes. What happens as the market becomes more competitive: Does price discrimination increase or decrease? From the above statements, it would seem that as market concentration increases, so should price discrimination. Theoretical studies contradict that intuition, however. Borenstein (1985), Holmes (1989), and Gale (1993) show that price discrimination may increase as the market becomes more competitive. For example, in Gale's theoretical model there is more price discrimination under duopoly than under monopoly.

This paper tests the hypothesis that higher market concentration lowers price discrimination in the airline market. The airline market is well-suited for empirical analysis of the theory. Empirical evidence to support or reject the hypothesis is scant, however. Despite growing literature on airline pricing, few analysts have examined the price-discriminatory mechanisms that airline use. The existing studies of the airline market show that as market concentration increases, so does the average price level (Borenstein (1992), Morrison and Winston (1990)). In the only empirical paper that studied the relationship between the distribution of fares for individual flights and market concentration in the airline market, Borenstein and Rose (1994) found a negative effect of market concentration on price dispersion. However, no studies have analyzed the effect of market concentration on price discrimination in the airline market. Unlike previous studies of airline pricing that focused on the average fare on each flight, this paper uses individual airline ticket prices and ticket restrictions. Price 
discrimination is measured with the effect of ticket restrictions on airfare.

The large dispersion in airfares paid by passengers traveling on the same flight has been scrutinized by both consumer groups and the press, who question the fairness of charging different prices for "the same good": a seat on a given flight. The variation in airfares can be either justified by cost differences (i.e., cost-based) or discriminatory (i.e., demand-based). Airlines price discriminate in two ways: first, by offering consumers a range of packages, or combinations of fares and restrictions attached to the tickets; and second, by restricting the number of discounted seats on each flight. The first type of price discrimination is known as second-degree or self-selection price discrimination. Consumers choose their preferred version of a product based on their willingness to pay for specific attributes of the good (e.g., time, convenience, flexibility). The second type is a case where carriers use a rationing device and limit the supply of the cheaper good. Both are combined in this analysis.

Travel restrictions attached to cheaper tickets make it costly for consumers to obtain discounts. That way, air carriers separate price-sensitive consumers with relatively low disutility from travel restrictions from price-inelastic consumers with high disutility from ticket restrictions. For example, Saturday-night stayover and advance-purchase requirements are designed to discourage price-inelastic consumers from buying cheaper tickets on a given flight. ${ }^{1}$ This paper separates cost-based route and carrier effects from discriminatory effects on price in order to test whether market concentration affects price discrimination.

Section I explains how air carriers price discriminate and how price discrimination may change with market concentration. Section II describes the data used in this paper. Section III presents the model, while Section IV discusses the results of the two models used: one that has fixed price discrimination and another that allows price discrimination to vary with market concentration and with

\footnotetext{
${ }^{1}$ Advance-purchase discounts have cost-based justification as well (see Borenstein and Rose (1994)).
} 
the carrier's market share. Section V offers conclusions. Using two different types of ticket restrictions to measure price discrimination, the study finds that the more competitive the market, the greater the price discrimination on the route.

\section{Airline Price Discrimination}

Price discrimination means charging different prices to different consumers, where the price difference cannot be fully explained by differences in cost. To price discriminate successfully, a firm must have some market power to be able to charge prices above marginal cost, the population of consumers must be heterogeneous (otherwise the firm could not separate the market), and product resale must be impossible or costly, to prevent arbitrage.

The air transportation market allows for price discrimination. Barriers to entry arising from sunk costs, scale economies, and hub-and-spoke systems give carriers market power even on relatively competitive routes. Airlines differentiate among themselves by occupying different slots in flight schedules, and by offering different route networks. For example, a carrier with a vast number of connections to the West Coast differentiates itself from a carrier flying only along the East Coast, even if both sell tickets for the Boston-Miami route. Such a market is therefore monopolistically competitive. Furthermore, consumers differ because of their varying price elasticities of demand. ${ }^{2}$ Although the resale of airline tickets is possible, it involves high search costs and does not eliminate restrictions, such as blackout days or time-of-day constraints.

In order to price discriminate, firms need to be able to separate consumer groups with different demand elasticities. They do it by attaching various restrictions to cheaper tickets, thereby making them unattractive to consumers with a high valuation of time or convenience and a low price elasticity

\footnotetext{
${ }^{2}$ The effect could also be measured by time or convenience elasticities of demand.
} 
of demand. Although some restrictions may lower the airline's costs by raising expected load factors, others mainly screen consumers on the basis of their utility functions.

Consumers maximize their expected utility from flying. They choose between various pricerestriction packages, such as between low price-high inconvenience and high price-no restrictions combinations. The choice depends on the consumer's elasticity of demand with respect to convenience, time, or money.

Carriers can successfully price discriminate between different consumer groups only if the difference in demand elasticities is significant. Figure 1 shows a diagram where the business passengers' indifference curve $\left(\mathrm{U}_{\mathrm{B}}\right)$ and the tourist passengers' indifference curve $\left(\mathrm{U}_{\mathrm{T}}\right)$ are far enough apart so that the carrier can sell two separate price-restriction combinations. ${ }^{3}$ The dotted lines indicate the carrier's indifference curves, while the solid line connects the observed price-restriction packages available to consumers. Arrows indicate the direction of increasing utility. In this simple two-type model, the business consumers choose to pay $\mathrm{P}_{\mathrm{B}}$, while the tourist consumers choose to pay $\mathrm{P}_{\mathrm{T}}$. Price discrimination is more likely to exist in markets where the population is dispersed (with a mixture of business and tourist passengers) and the volume of travel is large.

With more firms in the market, price discrimination can increase or decrease. On the one hand, as the market becomes more competitive, carriers may be forced to charge their marginal cost, leading to lower price discrimination. On the other hand, carriers may be forced to charge tourist consumers their marginal cost, but still be able to retain high markups on their captive, or business, consumers. Carriers' unique flight schedules (routes, flight frequency, and airport dominance) as well as frequent flier plans induce consumers to favor specific carriers, even when fares and ticket restrictions are

${ }^{3}$ In other words, the incentive compatibility constraint is satisfied. 
equal. ${ }^{4}$ Therefore, airlines may have market power in some market segments but not in others, possibly leading to higher price discrimination on more competitive routes.

Price discrimination is usually thought of as a way to extract as much consumer surplus as possible from each group of consumers, given their utility functions (demand elasticities, crosselasticities, etc.) and income. It is therefore associated with raising prices for less elastic consumers. But in the case of airlines, price discrimination is exhibited through fare discounts. Hence, changes in price discrimination involve changes in discounts given to more price elastic consumers. In this case, if higher competition reduces fares charged to price-elastic travelers, it may involve an increase in price discrimination - the discount associated with any given ticket restriction may be greater.

Borenstein and Rose (1994) found a negative effect of concentration on price dispersion. This study tests whether higher market concentration leads to lower price discrimination, where price discrimination is measured with marginal implicit prices of ticket restrictions, derived from a hedonic regression of ticket prices on ticket and route characteristics.

\section{Data}

This study uses data collected from the electronic version of the Official Airline Guide. The data include ticket information for flights on 12 different routes on the same day: Thursday, September 28, 1995. The date was picked to avoid summer or holiday peaks, as well as weekend travel. Selecting a single day eliminates price differences due to travel on different days of the week. The data include fares offered for sale at various times before the scheduled travel date. The earliest data include fares offered 35 days prior to departure, followed by fares offered at 21 days prior to departure, 14 days prior to departure, and finally 2 days prior to departure. A variable was constructed to control for the

\footnotetext{
${ }^{4}$ See Borenstein (1989) for a discussion of the effect of airport dominance.
} 
number of days prior to departure the fare was offered. The routes selected and carriers serving those routes are listed in Table 1. The routes were selected arbitrarily and range from highly concentrated to quite competitive.

The fares included both round-trip and one-way tickets, first class and coach tickets. Each observation contains specific information on a single ticket: the ticket price, ${ }^{5}$ the number of days prior to departure the fare was last offered, whether the fare was for a one-way or a round-trip ticket, whether the flight is direct or includes a stop, whether the seat is in a first-class or a coach cabin, ticket restrictions attached to the fare (see below), and the name of the carrier.

\section{A $\quad$ Ticket Restrictions}

The data include four restrictions that could be attached to each fare: a cancellation penalty, the number of days in advance that purchase is required, whether or not a Saturday-night stayover is required, and other (unspecified). The restrictions were highly correlated (see Table 2 for correlation coefficients). To avoid multicollinearity, one restriction at a time was included in the estimation. Other studies have found the advance-purchase requirement to be the best tool for airlines to segment their consumers. ${ }^{6}$ Since some restrictions may be correlated with the carrier's costs, the Saturday-night stayover requirement and the number of days of advance ticket purchase requirement were used as proxies for price discrimination. The requirement to stay over Saturday night is least likely to be correlated with cost effects.

\section{B $\quad$ Market Concentration}

${ }^{5}$ One-way fares were multiplied by two.

${ }^{6}$ In a theoretical model, Gale and Holmes (1993) found advance-purchase discounts to be a profitmaximizing way to sell tickets. 
Previous studies have found that using either the number of flights or the number of passengers on a route as a basis for market concentration calculations yields similar results. ${ }^{7}$ Since the data do not include the number of passengers, the number of direct flights on each route was used to calculate each carrier's market share and the Herfindahl-Hirschman Index (HHI) on each route. As an alternative measure, the number of carriers with direct flights on a given route was also used. ${ }^{8}$

\section{$\underline{\text { O }} \quad \underline{\text { Other Variables }}$}

Other variables include the following route and endpoint characteristics: the distance between the two endpoints, population and per-capita income in both cities, an indicator of tourist traffic on each route, a dummy variable indicating whether origin or destination city is a major hub, and a dummy variable indicating whether the origin or destination airport has a controlled number of landing slots. Arithmetic means of the origin and destination populations and of per-capita income in the two cities were used as exogenous measures of demand. The results did not change when either the origin population or the product of the two population measures was used instead. Following Brueckner, Dyer, and Spiller (1992) and Brueckner and Spiller (1994), the degree of tourist traffic was measured by the absolute difference in average January temperatures between the origin and destination. Destination airports with a regulated number of landing slots are Chicago O'Hare, Washington National, John F. Kennedy, and La Guardia. Table 3 lists the variables used in the paper, with their means and standard deviations.

\footnotetext{
${ }^{7}$ See Bailey, Graham and Kaplan (1985), Borenstein (1991), and Borenstein and Rose (1994).
}

${ }^{8}$ Some studies have used the number of potential competitors on the route (i.e., carriers that are located at one or both ends of the route, even if they are not currently operating on the route). However, Borenstein (1992) and Hurdle et al. (1989) showed that the number of potential competitors has a much smaller effect on ticket prices than the number of carriers actually operating on a given route. Borenstein (1989) also found the route market share to be a better predictor of ticket price than the airport market share. 


\section{D $\quad$ Price Dispersion}

Price dispersion on each route was calculated using several different measures (standard deviation, the ratio of standard deviation to the mean, the ratio of the highest to the lowest price). Negative correlation between market concentration and each of the price dispersion measures shows that fares on competitive routes are more dispersed than fares on concentrated routes (see Table 4). In other words, the more competitive the route, the higher the price dispersion. The result is consistent with the Borenstein and Rose (1994) finding. Although price dispersion is likely to be correlated with price discrimination, the above result does not isolate any cost effects. The section below specifies the econometric model used to isolate price discrimination from cost and other factors affecting airfares.

\section{Model}

\section{A $\quad \underline{\text { Restricted Model }}$}

A restricted model was first estimated, where price discrimination is assumed not to vary with market concentration. The assumption will be relaxed below. The model is a reduced-form regression of airfare on ticket restrictions, market concentration on the route, the carrier's market share, and other route- and ticket-specific factors:

$$
\begin{aligned}
\mathrm{P}_{\mathrm{ijk}}= & \beta_{0}+\beta_{1} \mathrm{R}_{\mathrm{ijk}}+\beta_{2} \text { HHI }_{\mathrm{i}}+\beta_{3} \mathrm{~S}_{\mathrm{ij}}+\beta_{4} \text { DIST }_{\mathrm{i}}+\beta_{5} \text { DISTSQ }_{\mathrm{i}}+\beta_{6} \text { AVGPOP }_{\mathrm{i}}+\beta_{7} \text { AVGINC }_{\mathrm{i}}+ \\
& +\beta_{8} \text { TEMP }_{\mathrm{i}}+\beta_{9} \text { HUB }_{\mathrm{ij}}+\beta_{10} \text { SLOTS }_{\mathrm{i}}+\beta_{11} \text { ONEWAY }_{\mathrm{ijk}}+\beta_{12} \text { FIRST }_{\mathrm{ijk}}+\beta_{13} \text { DAYS }_{\mathrm{ijk}}+\epsilon_{\mathrm{ijk}}
\end{aligned}
$$

where $\mathrm{P}$ is the round-trip airfare; $\mathrm{R}$ is a ticket restriction (a Saturday-night stayover requirement or an advance-purchase requirement); HHI is the Herfindahl index based on the number of each carrier's direct flights on the route; $\mathrm{S}$ is the carrier's market share based on the number of direct flights on the 
route; DIST and DISTSQ are the distance between the two endpoints and distance squared, respectively; AVGPOP is the average population in the two cities; AVGINC is the average per-capita income in the two cities; TEMP is the absolute difference in mean January temperatures between the origin and destination; HUB is a dummy variable equal to 1 if the carrier has a hub in the origin or destination; SLOTS is a dummy variable equal to 1 if the number of landing slots at either airport is regulated; ONEWAY is a dummy variable equal to 1 for one-way tickets; FIRST is a dummy variable equal to 1 for first-class tickets; and DAYS indicates the number of days prior to departure the fare was last offered. Subscript $i$ denotes route, subscript $j$ a carrier, and subscript $k$ a particular ticket for the carrier on the route. As the specification shows, some variables vary only among routes (i.e., HHI, DIST, DISTSQ, AVGPOP, AVGINC, TEMP, and SLOTS), others vary among the carriers on the route (i.e., $\mathrm{S}$ and $\mathrm{HUB}$ ), while some of the variables vary among individual tickets (i.e., $\mathrm{P}, \mathrm{R}$, ONEWAY, FIRST, and DAYS). Ticket restrictions are expected to have a negative effect on airfare, and market share to have a positive effect.

\section{B $\quad$ Unrestricted Model}

Price discrimination in the restricted model above is measured by $\beta_{1}$ and is assumed not to vary with market concentration. The unrestricted model below allows for price discrimination to vary with market concentration:

$$
\begin{aligned}
\mathrm{P}_{\mathrm{ijk}}= & \alpha_{0}+\mathrm{R}_{\mathrm{ijk}}\left(\gamma_{0}+\gamma_{1} \text { HHI }_{\mathrm{i}}+\gamma_{2} \mathrm{~S}_{\mathrm{ij}}\right)+\alpha_{1} \text { HHI }_{\mathrm{i}}+\alpha_{2} \mathrm{~S}_{\mathrm{ij}}+\alpha_{3} \text { DIST }_{\mathrm{i}}+\alpha_{4} \text { DISTSQ }_{\mathrm{i}}+\alpha_{5} \text { AVGPOP }_{\mathrm{i}}+ \\
& +\alpha_{6} \text { AVGINC }_{\mathrm{i}}+\alpha_{7} \text { TEMP }_{\mathrm{i}}+\alpha_{8} \text { HUB }_{\mathrm{ij}}+\alpha_{9} \text { SLOTS }_{\mathrm{i}}+\alpha_{10} \text { ONEWAY }_{\mathrm{ijk}}+\alpha_{11} \text { FIRST }_{\mathrm{ijk}}+ \\
& +\alpha_{12} \text { DAYS }_{\mathrm{ijk}}+v_{\mathrm{ijk}}
\end{aligned}
$$

The variables are defined as above. Equation (2) allows for the effect of price discrimination to vary 
with market concentration:

$\partial \mathrm{P}_{\mathrm{ijk}} / \partial \mathrm{R}_{\mathrm{ijk}}=\gamma_{0}+\gamma_{1} \mathrm{HHI}_{\mathrm{i}}+\gamma_{2} \mathrm{~S}_{\mathrm{ij}}$

where $\gamma_{1}$ measures the effect of market concentration, and $\gamma_{2}$ the effect of carrier's market share on price discrimination.

\section{Results}

\section{A $\quad \underline{\text { Restricted Model }}$}

Equation (1) was estimated using OLS. ${ }^{9}$ Fixed-effects estimation with carrier dummies was used to control for carrier-specific characteristics. ${ }^{10}$ Table 5a presents the results with the Saturdaynight stayover requirement, while Table $5 \mathrm{~b}$ presents the results with the advance-purchase requirement. The effect of a ticket restriction on price (price discrimination) was negative and significant, whether the Saturday-night stayover or the advance-purchase requirement was used. Adding a Saturday-night stayover requirement resulted, on average, in a \$297.05 drop in the ticket price. Increasing the advance-purchase requirement by a day resulted in a $\$ 9.40$ decrease in the ticket price. For example, a ticket with a 14-day advance purchase requirement cost $\$ 131.60$ less than a similar ticket on the same

${ }^{9}$ Following Graham, Kaplan and Sibley (1983), HHI is assumed to be exogenous in airfare estimation. Entry barriers prevent new carriers from entering city-pair routes (e.g., limited gate access, incumbent airlines' hub-and-spoke systems, and scale economies in network size). Computerized reservation systems, frequent flier programs, and travel agents' promotion systems raise switching costs and create further scale economies. All of these factors create high costs of entry into the airline industry. In the short run, then, concentration in any given city-pair market can be assumed to be fixed.

${ }^{10}$ Airlines set ticket prices based not only on the specific route conditions, but also on their overall market position, the availability of gates and planes, etc. To the extent that ticket prices are correlated with some unobserved, carrier-specific attributes, there may be an omitted-variable bias. The carrier dummies control for some of those effects. 
route without the requirement. ${ }^{11}$

In the first regression, the effect of a carrier's market share on price is positive and statistically significant. A 10 percent increase in a carrier's market share results in a $\$ 50.20$ increase in ticket price (a 4.3 percent increase, calculated at the mean). The effect of market concentration was insignificant, whether the carrier's market share was included or not. ${ }^{12}$ One-way tickets as well as first-class tickets commanded significantly higher fares than round-trip or coach tickets. Larger population in either origin or destination led to higher fares, but the mean per-capita income in endpoint cities was insignificant. Flights with relatively more tourist traffic have somewhat lower fares. The measure is not highly significant, possibly because the travel date is in September.

Since fares were offered at various times prior to departure, the data allow for examination of how prices change as the departure date gets closer. As it comes closer to the departure date, cheaper fares disappear, leaving only more expensive tickets for sale. Indeed, the coefficient on the DAY variable was negative in all specifications. Waiting an additional day to buy a ticket raises the fare by around $\$ 1$, controlling for other ticket attributes. To test whether the effect of time to departure varied by market concentration on the route, DAY was interacted with HHI. The coefficient on the interaction term was insignificant.

\section{B $\quad$ Unrestricted Model}

The restricted model in Equation (1) assumed that price discrimination did not vary with

${ }^{11}$ The effect of ticket restrictions on airfare was similar when a double-log specification was used instead. In particular, the estimated coefficient on the STAY dummy was -0.221 . Evaluated at the mean fare, the discount for Saturday-night stayover equals: $\partial \mathrm{P} / \partial \mathrm{STAY}=\partial \operatorname{lnP} / \partial \mathrm{STAY} \times \mathrm{P}=-0.221 \times 1166=-\$ 257.69$.

${ }^{12} \mathrm{As}$ an alternate measure of market concentration, the number of carriers with direct flights was used. The coefficient on the variable was negative and significant at the 10 percent level (more carriers on a route lead to lower fares). The estimated coefficients on the other variables were unaffected by the choice of the market concentration measure. 
market concentration. The unrestricted model in Equation (2) was also estimated with fixed carrier effects. The results of the regression with the Saturday-night stayover requirement are shown in Table 6a. The estimated price discrimination is as follows:

$\partial \mathrm{P}_{\mathrm{ijk}} / \partial \mathrm{Sat}_{\mathrm{ijk}}=-700.8+2196.4 \mathrm{HHI}_{\mathrm{i}}-363.0 \mathrm{~S}_{\mathrm{ij}}$

Equation (4) indicates that for a given level of market share, the higher the market concentration on a route, the lower the price discrimination, that is, the lower the price discount for a Saturday-night stayover restriction. ${ }^{13}$ The table below shows the effect of a Saturday-night stayover ticket restriction on airfare, calculated at the 25th, 50th, and 75th percentiles of $\mathrm{HHI}$ for the sample at the mean value of market share. The higher the market concentration on a route, the lower the effect of the restriction on airfare.

\section{The Effect of a Saturday-Night Stayover Requirement on Ticket Price by Market Concentration}

\begin{tabular}{||c|c|c||}
\hline \multicolumn{2}{|c|}{ HHI } & $\begin{array}{c}\text { Price discount for Saturday- } \\
\text { night stayover } \\
(\$)\end{array}$ \\
\hline \hline 25th percentile & 0.1529 & -424.49 \\
\hline 50th percentile & 0.1640 & -400.11 \\
\hline 75th percentile & 0.2511 & -208.80 \\
\hline
\end{tabular}

The results are consistent with the hypothesis that as more carriers operate on a given route, the carriers' competition for tourist consumers (i.e., consumers with elastic demand) increases, while fares

\footnotetext{
${ }^{13}$ Although HHI and S are positively correlated, the correlation coefficient is only 0.33 . Therefore the effect of one of the variables can be evaluated without altering the level of the other.
} 
charged to business consumers (i.e., consumers with inelastic demand) stay high, holding cost effects constant. As a result, price discrimination is higher on routes with more competition and lower market concentration. The effect of market concentration is independent of whether market share is included or not-the results were almost identical (and statistically not significantly different) when the interaction with market share variable was omitted from the regression.

The effect of market share on price discrimination is the opposite: the higher the carrier's market share on a given route, the larger the price discrimination by the carrier, holding market concentration constant (although the result was not statistically significant). If a table similar to the one above was constructed for different levels of market share holding market concentration constant, it would show that individual carriers with more market power on a route price discriminate more.

To test whether the result is robust, the number of days of advance purchase requirement was used instead of the Saturday-night stayover requirement as the measure of restriction to quantify the degree of price discrimination (Table 6b). The price discrimination effect is measured in this case as the discount on airfare for increasing the advance-purchase requirement by one day. The price discrimination effect derived from the estimated equation is as follows:

$\partial \mathrm{P}_{\mathrm{ijk}} / \partial \mathrm{Adv}_{\mathrm{ijk}}=-33.8+174.9 \mathrm{HHI}_{\mathrm{i}}-72.8 \mathrm{~S}_{\mathrm{ij}}$

Using the advance-purchase requirement does not change the result that price discrimination decreases with market concentration on a route. The table below shows the average effect on airfare of increasing an advance-purchase requirement by one day, calculated at the 25 th, 50 th, and 75 th percentiles of HHI for the sample at the mean value of market share. 
The Effect of an Advance Purchase Requirement on Ticket Price, by Market Concentration

\begin{tabular}{||c|c|c||}
\hline \multicolumn{2}{|c|}{ HHI } & $\begin{array}{c}\text { Price discount for each day of } \\
\text { Advance Purchase } \\
(\$)\end{array}$ \\
\hline \hline 25th percentile & 0.1529 & -19.0 \\
\hline 50th percentile & 0.1640 & -17.1 \\
\hline 75th percentile & 0.2511 & -1.8 \\
\hline
\end{tabular}

As with the Saturday-night stayover requirement above, the higher the market concentration on a route, the smaller the effect of the restriction on airfare. The result remains almost identical when the interaction of the advance-purchase requirement with market share is omitted from the regression. ${ }^{14}$

\section{Summary and Conclusion}

Using the effect of individual ticket restrictions on airfare as a measure of price discrimination by air carriers, this study finds that price discrimination decreases with market concentration. Since firms in perfectly competitive markets cannot price discriminate, intuition suggests that price discrimination should increase with market concentration. However, even on more competitive routes, each carrier's unique market position (route schedule, airport dominance, frequent flier plan) enables it to retain market power with respect to its business (inelastic) consumers, but not tourist (elastic) consumers. Travelers buying unrestricted tickets tend to prefer a particular carrier. Therefore, carriers

\footnotetext{
${ }^{14}$ When market share and market concentration were based on the total number of flights on a route instead of just direct flights (i.e., both direct and connecting flights), the results were similar. The derived price discrimination equation for the Saturday-night stayover requirement was: $\partial \mathrm{P}_{\mathrm{ijk}} / \partial \mathrm{Sat}_{\mathrm{ijk}}=-806.1+4765.0 \mathrm{HHI}_{\mathrm{i}}$ $619.9 \mathrm{~S}_{\mathrm{ij}}$, while for the advance-purchase requirement: $\partial \mathrm{P}_{\mathrm{ijk}} / \partial \mathrm{Adv}_{\mathrm{ijk}}=-46.7+323.2 \mathrm{HHI}_{\mathrm{i}}-71.0 \mathrm{~S}_{\mathrm{ij}}$. In both cases higher market concentration leads to lower price discrimination, while higher market share leads to more price discrimination by a carrier.
} 
on competitive routes are forced to lower their tourist fares, but they are able to maintain high markups on their business fares. Even when carriers face competition on a route, they effectively compete only for the price-elastic segment of the market, while retaining their market power in the other market segment. As a result, the more competitive routes have more price discrimination. 


\section{References}

Bailey, Elizabeth E., David R. Graham, and Daniel P. Kaplan. 1985. Deregulating the Airlines. Cambridge, Mass.: MIT Press.

Borenstein, Severin. 1985. "Price Discrimination in Free-Entry Markets." RAND Journal of Economics, vol. 16 (Autumn), pp. 380-97.

. 1989. "Hubs and High Fares: Dominance and Market Power in the U.S. Airline Industry." RAND Journal of Economics, vol. 20 (Autumn), pp. 344-65.

. 1991. "The Dominant-Firm Advantage in Multi-Product Industries: Evidence from the U.S. Airlines." Quarterly Journal of Economics, vol. 106 (November), pp. 1237-66.

. 1992. "The Evolution of U.S. Airline Competition." Journal of Economic Perspectives, vol. 6 (Spring), pp. 45-73.

Borenstein, Severin and Nancy L. Rose. 1994. "Competition and Price Dispersion in the U.S. Airline Industry.” Journal of Political Economy, vol. 102 (August), pp. 653-83.

Brueckner, Jan K., Nichola J. Dyer, and Pablo T. Spiller. 1992. "Fare Determination in Airline Huband-Spoke Networks.” RAND Journal of Economics, vol. 23 (Autumn), pp. 309-33.

Brueckner, Jan K. and Pablo T. Spiller. 1994. "Economics of Traffic Density in the Deregulated Airline Industry." Journal of Law and Economics, vol. 37 (October), pp. 379-415.

Gale, Ian L. 1993. "Price Dispersion in a Market with Advance-Purchases." Review of Industrial Organization, vol. 8 (August), pp. 451-64.

Gale, Ian L. and Thomas J. Holmes. 1993. "Advance-Purchase Discounts and Monopoly Allocation of Capacity." American Economic Review, vol. 83 (March), pp. 135-46.

Graham, David R., Daniel P. Kaplan, and David S. Sibley. 1983. "Efficiency and Competition in the Airline Industry." Bell Journal of Economics, vol. 14 (Spring), pp. 118-38.

Holmes, Thomas J. 1989. "The Effects of Third-Degree Price Discrimination in Oligopoly." American Economic Review, vol. 79 (March), pp. 244-50.

Hurdle, Gloria J., Richard L. Johnson, Andrew S. Joskow, Gregory J. Werden, and Michael A. Williams. 1989. "Concentration, Potential Entry, and Performance in the Airline Industry." Journal of Industrial Economics, vol. 38 (December), pp. 119-39.

Morrison, Steven A. and Clifford Winston. 1990. "The Dynamics of Airline Pricing and Competition." American Economic Review, vol. 80 (May), pp. 389-93. 
Figure 1: Market Segmentation by Air Carriers

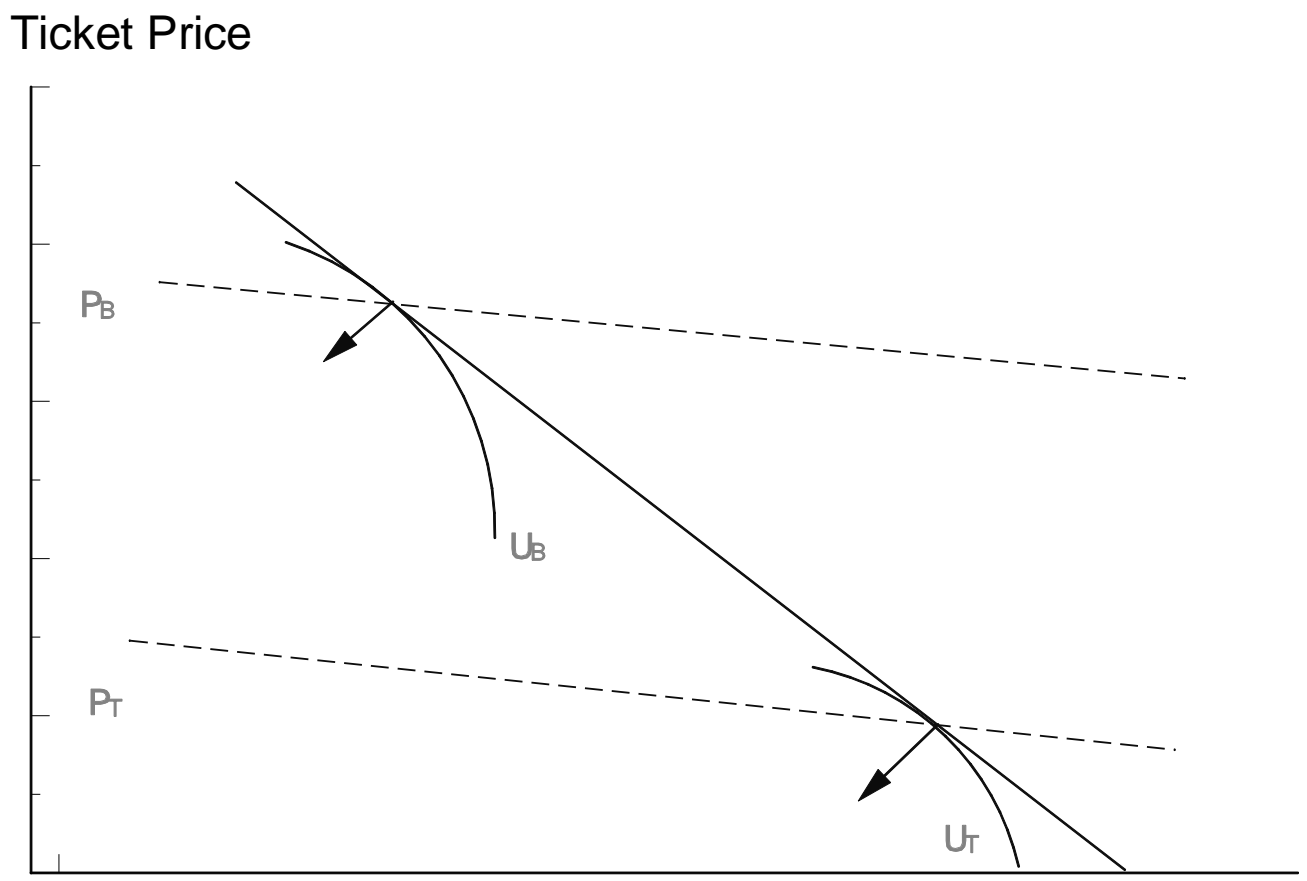

Ticket Restrictions 
Table 1: Routes and Carriers Serving Each Route

\begin{tabular}{|c|c|c|}
\hline Origin & Destination & Carriers $^{a}$ \\
\hline Atlanta & Portland & $\begin{array}{l}\text { AA, CO, DL, HP, NW, } \\
\text { TW, UA }\end{array}$ \\
\hline Boston & San Francisco & $\begin{array}{l}\text { AA, CO, DL, HP, NW, } \\
\text { TW, UA, US }\end{array}$ \\
\hline Boston & Cleveland & $\begin{array}{l}\text { AA, CO, DL, NW, TW, } \\
\text { UA, US }\end{array}$ \\
\hline Boston & St. Louis & $\begin{array}{l}\text { AA, CO, DL, NW, TW, } \\
\text { UA, US, YX }\end{array}$ \\
\hline Dallas & Memphis & AA, DL, NW \\
\hline Denver & Houston & $\mathrm{AA}, \mathrm{CO}, \mathrm{DL}, \mathrm{UA}$ \\
\hline Detroit & Minneapolis & $\mathrm{AA}, \mathrm{CO}, \mathrm{NW}, \mathrm{UA}$ \\
\hline Milwaukee & St. Louis & AA, TW, UA, YX \\
\hline New York & Los Angeles & $\begin{array}{l}\text { AA, CO, DL, FF, HP, NW, } \\
\text { TW, UA, US, YX }\end{array}$ \\
\hline Philadelphia & Chicago & $\begin{array}{l}\text { AA, CO, DL, HP, NW, } \\
\text { TW, UA, US }\end{array}$ \\
\hline Pittsburgh & Orlando & $\mathrm{CO}, \mathrm{DL}, \mathrm{UA}, \mathrm{US}$ \\
\hline St. Louis & Washington & $\begin{array}{l}\text { AA, CO, DL, NW, TW, } \\
\text { UA, US, WN }\end{array}$ \\
\hline
\end{tabular}

a AA - American

CO - Continental

DL - Delta

FF - Tower Air

HP - America West

NW - Northwest

TW - TWA

UA - United

US - USAir

WN - Southwest

YX - Midwest Express 
Table 2: Correlation Coefficients among Ticket Restrictions

\begin{tabular}{lcccc}
\hline \hline Ticket Restrictions & $\begin{array}{c}\text { Cancellation } \\
\text { Penalty }\end{array}$ & $\begin{array}{c}\text { Advance } \\
\text { Purchase }\end{array}$ & $\begin{array}{c}\text { Saturday } \\
\text { Night }\end{array}$ & Other \\
\hline Cancellation Penalty & 1.0000 & & \\
$\begin{array}{l}\text { Advance Purchase } \\
\text { Requirement }\end{array}$ & 0.7573 & 1.0000 & & \\
$\begin{array}{l}\text { Saturday Night } \\
\text { Stayover Requirement }\end{array}$ & 0.9463 & 0.7160 & 1.0000 & \\
\begin{tabular}{l} 
Other \\
\hline \hline
\end{tabular} & 0.8992 & 0.6823 & 0.8542 & 1.0000 \\
\hline
\end{tabular}


Table 3: Descriptive Statistics

\begin{tabular}{lcc}
\hline \hline Description & Mean & Standard Deviation \\
\hline Round-Trip Airfare & 1165.91 & 866.54 \\
Number of Days Prior to Departure & 20.77 & 11.22 \\
One-Way & 0.61 & 0.49 \\
Direct Flight & 0.37 & 0.48 \\
First Class & 0.21 & 0.41 \\
Cancellation Penalty & 0.41 & 0.49 \\
Advance Purchase Requirement (\# days) & 4.18 & 6.10 \\
Saturday Night Stayover Requirement & 0.39 & 0.49 \\
Other Restriction & 0.46 & 0.50 \\
Distance & 1773.40 & 883.57 \\
Average Population & 5498.02 & 2957.21 \\
Average Per Capita Income & 21244.14 & 1611.20 \\
Difference in Mean January Temperatures & 12.93 & 13.85 \\
Market Share (Direct Flights) & 0.16 & 0.15 \\
Market Share (All Flights) & 0.15 & 0.07 \\
HHI (Direct Flights) & 0.24 & 0.15 \\
HHI (All flights) & 0.15 & 0.05 \\
Hub Dummy & 0.26 & 0.49 \\
Restricted Slots Dummy & 0.60 & \\
\hline \hline
\end{tabular}


Table 4: Correlation Between Market Concentration and Price Dispersion

\begin{tabular}{ll}
\hline \hline Price Dispersion Measure & HHI \\
\hline Standard Deviation & -0.4892 \\
$\mathrm{P}(80 \%)$ - P $(20 \%)$ & -0.5082 \\
Standard Deviation / Mean & -0.5599 \\
$(\mathrm{P}(80 \%)-\mathrm{P}(20 \%)) /$ Median & -0.5197 \\
$\mathrm{P}_{\mathrm{Max}} / \mathrm{P}_{\text {Min }}$ & -0.6549 \\
\hline \hline
\end{tabular}


Table 5a: Restricted Model with the Saturday Night Stayover Requirement

\begin{tabular}{llll}
\hline \hline & Coefficient & Standard Error & t-Statistic \\
\hline Intercept & -560.67 & 288.33 & -1.95 \\
Saturday Night Stayover Requirement & -297.05 & 56.89 & -5.22 \\
HHI & -224.68 & 241.81 & -0.93 \\
Market Share & 501.99 & 201.46 & 2.49 \\
Distance & 0.89 & 0.15 & 5.98 \\
Distance Squared & -0.00016 & 0.000051 & -3.05 \\
Average Population & 0.04 & 0.01 & 3.07 \\
Average Per Capita Income & 0.01 & 0.01 & 0.93 \\
January Temperature & -2.17 & 1.34 & -1.62 \\
Hub Dummy & -37.33 & 28.67 & -1.30 \\
Slots Dummy & -230.02 & 72.69 & -3.16 \\
One-Way & 665.15 & 56.23 & 11.83 \\
First Class & 869.80 & 28.52 & 30.50 \\
Number of Days Prior to Departure & -1.40 & 0.94 & -1.49 \\
\hline $\mathrm{N}$ & 2172 & & \\
\hline $\mathrm{R}{ }^{2}$ & 0.70 & & \\
\hline $\mathrm{F}$ & 390.15 & & \\
\hline \hline
\end{tabular}


Table 5b: Restricted Model with the Advance Purchase Requirement

\begin{tabular}{llll}
\hline \hline & Coefficient & Standard Error & t-Statistic \\
\hline Intercept & -826.79 & 284.07 & -2.91 \\
Advance Purchase Requirement & -9.40 & 2.46 & -3.82 \\
HHI & 132.15 & 241.83 & 0.55 \\
Market Share & 195.93 & 203.14 & 0.97 \\
Distance & 0.72 & 0.15 & 4.83 \\
Distance Squared & -0.00012 & 0.000051 & -2.26 \\
Average Population & 0.04 & 0.01 & 3.14 \\
Average Per Capita Income & 0.02 & 0.01 & 1.55 \\
January Temperature & -0.44 & 1.36 & -0.32 \\
Hub Dummy & -58.94 & 28.75 & -2.05 \\
Slots Dummy & -216.10 & 72.99 & -2.96 \\
One-Way & 851.69 & 30.59 & 27.85 \\
First Class & 873.35 & 28.92 & 30.20 \\
Number of Days Prior to Departure & -1.14 & 0.95 & -1.19 \\
\hline $\mathrm{N}$ & 2138 & & \\
\hline $\mathrm{R}^{2}$ & 0.70 & & \\
\hline $\mathrm{F}$ & 380.44 & & \\
\hline \hline
\end{tabular}


Table 6a: Unrestricted Model with the Saturday Night Stayover Requirement

\begin{tabular}{llll}
\hline \hline & Coefficient & Standard Error & t-Statistic \\
\hline Intercept & -811.08 & 281.79 & -2.88 \\
Saturday Night Stayover Requirement & -700.84 & 66.99 & -10.46 \\
Saturday Stayover $\times$ HHI & 2196.41 & 337.14 & 6.52 \\
Saturday Stayover × Market Share & -362.95 & 292.39 & -1.24 \\
HHI & -729.94 & 259.56 & -2.81 \\
Market Share & 574.53 & 223.34 & 2.57 \\
Distance & 0.89 & 0.14 & 6.15 \\
Distance Squared & -0.00016 & 0.000050 & -3.21 \\
Average Population & 0.06 & 0.01 & 4.24 \\
Average Per Capita Income & 0.03 & 0.01 & 2.29 \\
January Temperature & -2.47 & 1.31 & -1.89 \\
Hub Dummy & -32.40 & 27.92 & -1.16 \\
Slots Dummy & -264.33 & 71.11 & -3.72 \\
One-Way & 660.12 & 54.91 & 12.02 \\
First Class & 869.26 & 27.77 & 31.30 \\
Number of Days Prior to Departure & -1.52 & 0.92 & -1.66 \\
\hline $\mathrm{N}$ & 2172 & & \\
\hline $\mathrm{R}{ }^{2}$ & 0.72 & & \\
\hline $\mathrm{F}$ & 364.59 & & \\
\hline \hline
\end{tabular}


Table 6b: Unrestricted Model with the Advance Purchase Requirement

\begin{tabular}{llll}
\hline \hline & Coefficient & Standard Error & t-Statistic \\
\hline Intercept & -867.70 & 279.09 & -3.11 \\
Advance Purchase Requirement & -33.83 & 3.08 & -8.89 \\
Advance Purchase $\times$ HHI & 174.85 & 26.97 & 6.48 \\
Advance Purchase $\times$ Market Share & -72.81 & 24.17 & -3.01 \\
HHI & -433.00 & 258.66 & -1.67 \\
Market Share & 458.66 & 222.28 & 2.06 \\
Distance & 0.71 & 0.15 & 4.84 \\
Distance Squared & -0.00011 & 0.000050 & -2.18 \\
Average Population & 0.05 & 0.01 & 3.38 \\
Average Per Capita Income & 0.02 & 0.01 & 2.00 \\
January Temperature & -0.91 & 1.33 & -0.68 \\
Hub Dummy & -44.02 & 28.29 & -1.56 \\
Slots Dummy & -213.85 & 71.87 & -2.98 \\
One-Way & 851.25 & 30.09 & 28.29 \\
First Class & 867.65 & 28.42 & 30.53 \\
Number of Days Prior to Departure & -1.13 & 0.94 & -1.21 \\
\hline $\mathrm{N}$ & 2138 & & \\
\hline $\mathrm{R}{ }^{2}$ & 0.71 & & \\
\hline $\mathrm{F}$ & 346.98 & & \\
\hline \hline
\end{tabular}

